\title{
ASOCIACIONISMO CORAL EN EL CÁDIZ DEL S. XIX: EL ORFEÓN \\ GADITANO
}

\section{JUAN ANTONIO VERDÍA DÍA \\ IES LA CALETA (CÁDIZ)}

RESUMEN: En la actualidad, es necesario reivindicar el papel de la periferia a pesar de que la tradición musicológica ha tratado de reducir la actividad embrionaria del movimiento coral al norte de España. Aunque son comunes los elementos que vertebran los orfeones, como el sentido de nación, la pedagogía musical de base y el agrupamiento obrero, el caso gaditano fue independiente, y siguió en su fundación el modelo francés. Además, el Orfeón Gaditano fue una asociación muy popular en el Cádiz de la segunda mitad del siglo XIX, por lo que merece profundizarse en su estudio, a pesar de que la documentación que nos ha llegado sobre el mismo es realmente escasa.

Palabras clave: Sociedad, coral, Cádiz, obrero, pedagogía.

\section{CHORUS AND SOCIETY: THE “ORFEÓN GADITANO” IN $19^{\mathrm{TH}}$ CENTURY}

\begin{abstract}
The musicological tradition reduces the incipient activity of the choral movement to the north of Spain. At present, it is necessary to claim the role of the periphery. These working grouping, sense of nation, musical pedagogy of base, are the elements that set in the choruses. Definitely, tradition has constructed different speeches on the Chorus on which it is worth to go in depth, refutate or put into context. The documentation that has come up to us from Cadiz chorus is very scarce. Nevertheless, it must have been a very popular society in the second half of 19th century.
\end{abstract}

KEYWORDS: Society, coral, Cadiz, worker, pedagogy. 


\section{Introducción}

El Orfeón Gaditano es una sección de la Academia de Santa Cecilia poco conocida, a pesar de que tuvo épocas en que era muy popular. Está ligado al movimiento obrero, pero sobre todo, a la difusión de la música culta entre las clases populares. A pesar de existir durante un periodo de tiempo relativamente largo, su vida pasó por numerosos momentos de crisis.

Los objetivos de este trabajo son la puesta en valor del Orfeón, resaltando su importancia dentro de la vida musical gaditana, demostrar la independencia del origen coral gaditano de la tradición catalana y destacar la importancia de la periferia peninsular en los movimientos musicales y asociaciones de la segunda mitad del siglo XIX español.

Para la realización de este artículo ha sido primordial el estudio de la documentación del Archivo Histórico Provincial de Cádiz, en concreto, el Archivo del Conservatorio y la caja dedicada al Orfeón, en la que los documentos aparecen ordenados por orden cronológico y sin número de folio. También ha sido vital el estudio de numerosos ejemplares de Diario de Cádiz que se conservan en la Hemeroteca de la Biblioteca Provincial, que tampoco presentan numeración de folio. Sin embargo, al tener cada ejemplar solo dos hojas, la localización de las noticias no representa dificultad alguna. Igualmente, hemos consultado el Archivo de Música y las cajas de documentación de la Banda de Música en el Archivo Municipal, cuyos papeles tampoco tienen numeración pero suelen estar agrupados en carpetas por temas o años.

\section{Orígenes del movimiento coralista}

Con toda seguridad, el espíritu asociativo del romanticismo burgués influyó en el movimiento coral aficionado, por lo que, con el nacimiento de las naciones, el coro se convierte en el vehículo ideal para la exaltación de determinados valores patrióticos.

"El liedertafel fundado en Berlín en 1808 por el músico Karl Friedrich Zelter (1758-1832) es considerado como la primera sociedad coral de este carácter y prototipo de género". ${ }^{1}$

1 CASARES RODICIO, Emilio (coordinador): Diccionario de la Música Española e Hispanoamericana, Madrid, SGAE, 1999, p. 23. 
El reinado de Isabel II propició algunas reformas, permitió el paso de las ideas europeas a España y fomentó el asociacionismo de la segunda mitad del XVIII, pero más orientado hacia la tertulia, el baile y las sociedades musicales. La entrada del Romanticismo en el país fue uno de las consecuencias de la vuelta de los emigrados. ${ }^{2}$

El término “orfeón” fue introducido por Guillaume Louis Bocquillon-Wilhem junto a un nuevo método de estudio del canto, pero la intencionalidad final era el establecimiento de la música popular y la unión del pueblo en torno a la música. ${ }^{3}$ Por la cercanía con el país vecino, la tradición supone que fue en Cataluña donde se inicia el movimiento coral. ${ }^{4}$

El éxito obtenido por Anselmo Clavé en su tipología de orfeón "La Fraternidad” de 1850, construido en torno a la clase trabajadora, hace que se vaya extendiendo el movimiento, sin embargo, el caso gaditano debió ser independiente, porque el francés Darhan utilizaba ya el método Wilhem en una escuela de Cádiz en 1851. ${ }^{5}$ Sabemos de su actividad mercantil, su formación musical parisina y su ascendencia francesa, ${ }^{6}$ por lo que le dedicaremos un estudio posterior.

Otra prueba que demuestra la independencia coral gaditana es la existencia en el Archivo Provincial de los estatutos de la Sociedad Artística Gaditana, de 1852, formada por los coristas de Cádiz y Sevilla. ${ }^{7}$

El caso más conocido del movimiento coral vasco parece haber seguido, como el del levante, un camino independiente al catalán. A principios del siglo XX también empiezan a proliferar en Asturias entidades corales en el seno de las Casas del Pueblo ${ }^{8}$, en cuyos orfeones socialistas se utilizaba la música como elemento de cohesión entre los obreros.

Hasta ahora se ha mantenido la idea de que en Andalucía el movimiento coral estuvo muy limitado, pero Joaquina Labajo pudo localizar siete agrupaciones entre 1860-1890 y

2 DÍAZ HUERGA, María Aurelia: "Las sociedades musicales en el Madrid de Isabel II", Anuario Musical, Madrid, CSIC, 2003, n. ${ }^{\circ}$ 58, 2003, p. 254.

3 CASARES RODICIO. Emilio: “Diccionario..., op. cit. p. 2, p. 23.

${ }^{4}$ CARBONELL I GUBERNA: "Aportaciones al estudio de la sociabilidad coral en la España Contemporánea", Hispania LXIII/2, Madrid, CSIC, n. . 214, 2003, p. 491.

5 BIBLIOTECA NACIONAL DE ESPAÑA (en adelante BNE), Hemeroteca digital, La Gaceta Musical de Madrid, n. ${ }^{\circ}$ 33, Año II, 17 de agosto de 1856, p. 3, disponible en http:/ / hemerotecadigital.bne.es/issue.vm?id=0003899819\&page=3\&search=darhan\&lang $=\mathrm{es}$

Página visitada el 1 de septiembre de 2019.

6 BARTOLOMEI, Arnaud: "La naturalización de los mercaderes franceses de Cádiz a finales del siglo XVIII y principios del XIX", Cuadernos de Historia Moderna, Madrid, Universidad Complutense, 2011, número X, p. 134.

7 VARIOS AUTORES. "Música en Cádiz", catálogo de la exposición. Archivo Histórico Provincial de Cádiz, Consejería de Cultura de la Junta de Andalucía. 2006. Información extraída de los Protocolos. Protocolo Cádiz, 5430. folios 9-16

8 CARBONELL I GUBERNA: “Aportaciones..., op. cit., p. 2, p. 498. 
Manuel Morales Muñoz estudió la influencia del modelo claveriano en la fundación de la sociedad coral La Estrella en 1863. Posteriormente, La Unión Coral Malagueña en 1887 y la Sociedad Coral de Málaga en 1913 vendrían a conformar un ejemplo de vida coral que compartiría con el Orfeón Obrero en 1912. ${ }^{9}$ En Sevilla se encuentran el Real Orfeón Sevillano y la Coral Sevillana, aparte de la Sociedad Filarmónica ${ }^{10}$.

La profundización en los estudios quizá permita descubrir más agrupaciones alrededor de otros centros andaluces industriales, como la cuenca de Huelva, Jerez, etc. Al identificar industrialización y movimiento coral se puede entender que el Norte y la zona Mediterránea sean más proclives a la creación de agrupaciones vocales de este tipo, pero no podemos descartar que en otras zonas con un cierto movimiento obrero ocurriera lo mismo.

En el resto de Andalucía se han estudiado los coros en Córdoba (unión ArtísticoMusical), Granada (Orfeón Granadino), Málaga (Sociedad Filarmónica). En Granada se funda la Sociedad Coral con los mismos fines y en el mismo año que en Cádiz ${ }^{11}$, en la provincia de Jaén se han estudiado las fundaciones del Orfeón Linarense en 1890, el Orfeón Jiennense de 1890, con 70 obreros, del Círculo de las Sociedades Obreras Confederadas, el Orfeón de Martos, de 1897, el Orfeón de Baeza de 1901, etc. ${ }^{12}$.

\section{Agrupaciones vocales contemporáneas del Orfeón}

La actividad de agrupaciones vocales en Cádiz debió de ser acusada en determinados momentos de la segunda mitad del siglo XIX, especialmente en los grupos dedicados a la música popular, ya que los coros y orquesta del conservatorio Odero o Santa Cecilia no sólo aparecen en actos pedagógicos, sino que también realizan actuaciones fuera de los centros:

"En la función del quinario del Nazareno, misa del maestro Dieryex, interpretada por el conjunto coral e instrumental del Conservatorio Odero, dirigido por Antonio de Rivas"13.

\footnotetext{
9 Ibidem, p. 501.

${ }^{10}$ MÉNDEZ MORENO, José Joaquín: “La Sociedad Filarmónica Sevillana en el siglo XIX: Antecedentes, orígenes y constitución”, Temas para la educación, Sevilla, Universidad Internacional de Andalucía, n. ${ }^{\circ}$ 29, septiembre 2014, p. 1.

${ }^{11}$ CASARES RODICIO: "Diccionario..., op. cit. p. 2, p. 23.

12 SÁNCHEZ LÓPEZ, Virginia: Jaén y la música en el siglo XIX. La vida musical de una provincia española a través de la prensa. Jaén, Universidad de Jaén. 2013, pp. 11, 145, 180 y 267.

13 BIBLIOTECA PROVINCIAL DE CÁDIZ (en adelante BPC), Hemeroteca. La información del lunes, caja PA PP 29, 21 de enero de 1929, s/f.
} 
Además de estos conjuntos relacionados con las academias "oficiales" de música, tenemos confirmada la existencia de numerosos conjuntos vocales: el más antiguo, sin duda, es la capilla de música de la catedral, que en la época de aparición del Orfeón está en decadencia, aunque aún conserva a los cantores e instrumentistas y aparece muy activa en funciones de cofradías y apoyada por el Orfeón en algunos actos.

\section{Fotografía n. ${ }^{0} 1$}

La tuna de la Facultad de Medicina en el Conservatorio. Aprox. 1931

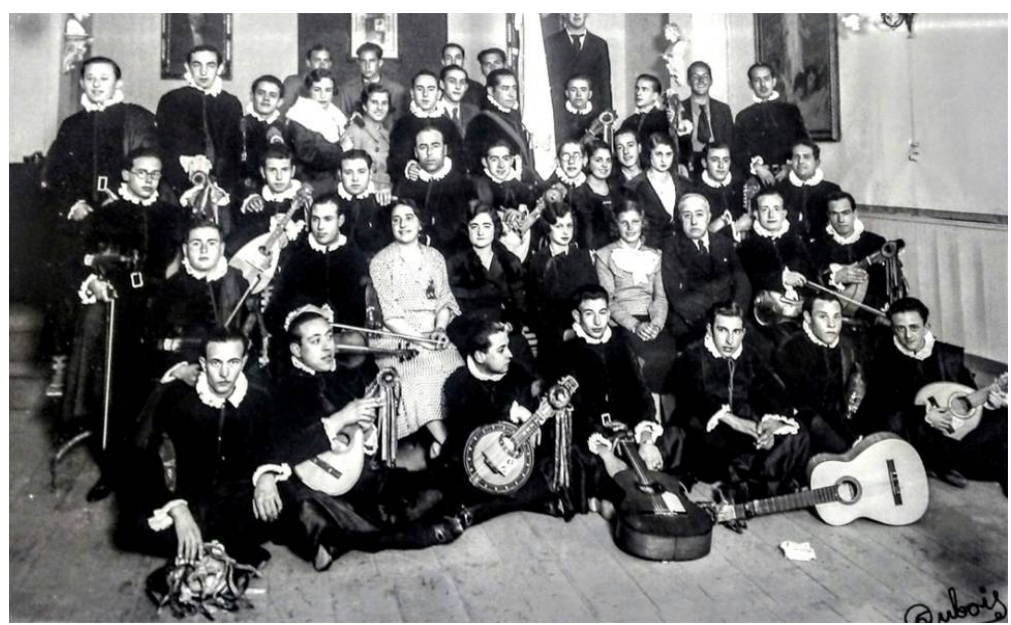

Fuente: Dubois. Exposición sobre el fotógrafo Dubois. ECCO. 2017.

Otra agrupación vocal característica de la época es la Estudiantina (Fotografía n. ${ }^{\circ}$ 1). En 1901 se tiene noticia de la tuna gaditana de Medicina interpretando "...entre otros números el intermezzo de "Cavalleria Rusticana" y el vals coreado "Siempre Cantar"14. En La Información del Lunes aparece la actuación de la Tuna Normalista (Fotografía n. ${ }^{\circ}$ 2) interpretando jotas, pasodobles, foxtrot, etc. La Filarmónica Gaditana es otro de los conjuntos vocales que suele acompañarse de una rondalla y de la que se comenta que está integrada por obreros ${ }^{15}$. También se anuncia la presentación de la Estudiantina del Centro Obrero de la Transatlántica, dirigida por Antonio Rivas en el Teatro Principal y el 24 y el 25 de enero, la Estudiantina Escolar.

Desde finales del XIX tenemos noticia de agrupaciones carnavalescas, pero es a principios del XX cuando se hacen más populares.

\footnotetext{
${ }^{14}$ BPC, Hemeroteca, Diario de Cádiz, 24 de febrero de 1901, s/f.

15 ARCHIVO HISTÓRICO PROVINCIAL DE CÁDIZ (en adelante AHPC), Gobierno Civil, caja 158, 21 de marzo de 1851, s/f.
} 


\section{Fotografía n. ${ }^{\circ} 2$}

\section{Estudiantina de la Escuela Normalista}

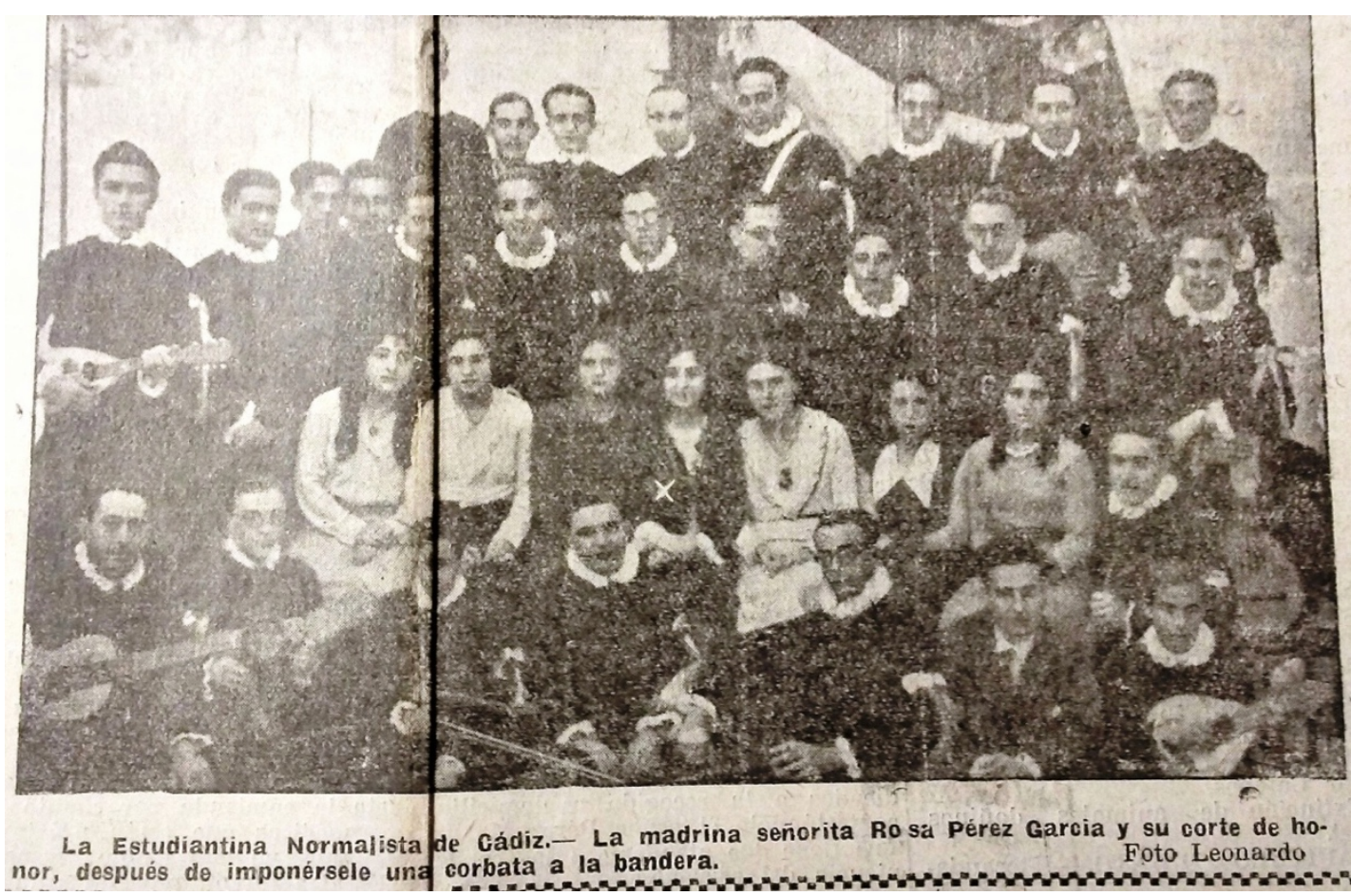

Fuente: BPC, Hemeroteca, Diario de Cádiz. 23 de enero de 1932.

\section{Funcionamiento del Orfeón}

Aunque esta sociedad nace en el seno de la Academia de Música, es independiente de la misma, a pesar de que los cargos están muy ligados al conservatorio y aunque el reglamento ${ }^{16}$ obliga al Orfeón a acudir a los conciertos celebrados en la Academia, sin recibir retribución alguna.

La Junta Directiva está formada por un director vicepresidente -la presidencia es la misma que la de la Academia- un subdirector archivero, tesorero, contador, secretario y vicesecretario. Estos cargos se eligen anualmente y presentan las cuentas a la asamblea cuatro veces al año. El director presidente nombra los jefes de cuerda, al subdirector y al ordenanza, dispone los ensayos, las obras, etc., y recibe el 10\% de los ingresos externos. El subdirector sustituye al director y además es el archivero, mientras que los demás cargos tienen las mismas atribuciones que los cargos de cualquier asociación. Los nuevos integrantes deben ser presentados por dos socios, y tienen que pasar un examen musical del director $y$ si aprueban, pasan a ser aspirantes y no pueden pertenecer a otra sociedad coral. Parece que eran muy puntillosos con las faltas de asistencia.

16 AHPC, Orfeón Gaditano, caja, 35638, s/n. 


\subsection{Economía}

Los orfeonistas no cobran cuando los conciertos son actos relacionados con los objetivos obreros de la sociedad, así que el rédito de los demás conciertos se acumula en una caja común hasta final de año, en que se reparte el 80\%. El dinero restante queda para atender casos de necesidad de los coralistas en un fondo social que se puede ampliar realizando un concierto a beneficio de un integrante que esté necesitado.

A pesar de que se mantiene mediante la aportación de socios, el Orfeón recibe ayudas oficiales, como aparece en la carta que se conserva del Ministro de la Gobernación, contestando respecto a la petición de que se acoja a los beneficios de la "Real Orden del 18 de octubre de 1885 de S.M. la Reina ba concedido a dicha asociación la cantidad de 90 pesetas para asociaciones destinadas a socorrer los obreros inutilizados en el trabajo..."17. La más habitual es la subvención del Ayuntamiento, como aparece en la carta del Alcaldía del 26 de junio de 1886: "Accediendo a lo solicitado por VS. ha acordado en cabildo de 19 del corriente conceder a esa sociedad coral la suma de 125 pesetas en concepto de subvención..."18.

\subsection{Organización de los ensayos}

Aparte de los jefes de cuerda tienen jefes de sección, que pasan una lista con las faltas de asistencia. Según el Art. 51, el número de orfeonistas se fija en sesenta, dispuestos de la siguiente forma:

\section{Tabla n. ${ }^{\circ} 1$}

\section{Esquema de organización de las cuerdas}

\begin{tabular}{|c|c|}
\hline 14 barítonos & 16 bajos \\
\hline 16 tenores primeros & 14 tenores segundos \\
\hline
\end{tabular}

Fuente: elaboración propia, según los datos de los Estatutos del Orfeón

Del 11 de marzo de 1884 se conserva el cuadrante de voces para preparar la serenata que se realiza el 18 de Marzo, y se recuerda en el mismo la parte del reglamento que habla de las faltas de asistencia ${ }^{19}$. De este documento podemos extraer las siguientes conclusiones: que es un conjunto masculino -como habíamos anunciado-, la división a cuatro voces del

${ }^{17}$ Ibidem, 9 de abril de $1886, \mathrm{~s} / \mathrm{n}$.

18 Ibídem ,26 de junio de 1886, s/n.

19 Ibídem, 11 de marzo de 1884, s/n. 
conjunto, el desequilibrio existente entre los tenores primeros y las demás cuerdas, más nutridas, a pesar de que estos suelen llevar la melodía, y que al menos en estos años iniciales llevaban un exhaustivo control de la asistencia, como también habíamos mencionado. Por eso, se conservan diversas circulares referidas a este tema ${ }^{20}$ y los requerimientos del secretario para que se personen determinados integrantes en la Academi ${ }^{21}$. Igualmente, tenemos unas siete listas de los orfeonistas con las anotaciones de haber faltado en un cuadrante, o también un resumen de las faltas, manuscrito, de julio y agosto ${ }^{22}$, donde se demuestra que la acumulación de ensayos es muy alta, casi diarios, lo que debe ser complejo en un grupo de aficionados con otras actividades profesionales.

\subsection{Pedagogía musical}

En cuanto a la forma de enseñanza musical, las clases se dividen en cuatro grupos: Estudios de la Teoría de la Música y Solfeo, Aprendizaje de coros de zarzuela y óperas, Música religiosa para formar capilla y Corales en conjunto para festivales públicos.

\subsection{Asistencia a otros actos}

La Junta del Orfeón participa y acude habitualmente de manera independiente del conservatorio a actos sociales, por ejemplo, del 19 de noviembre de 1884 se conserva, entre otras, la carta del secretario de la Escuela de Declamación del Liceo Dramático de Cádiz, invitando al Orfeón Gaditano a la inauguración del curso $^{23}$.

\subsection{Invitaciones}

En cuanto a la asistencia de público a los conciertos, parece ser que la fórmula habitual era la invitación de sociedades y personalidades, y se esperaba la respuesta sobre cuántos asistirán al concierto. De esta manera, se conserva la carta de la sociedad gaditana de Gas, del 11 de junio de $1886^{24}$, la del Regimiento de Infantería n. ${ }^{\circ} 15$, que devuelve 20 billetes por no poder asistir al concierto, la del Coronel del Regimiento de infantería Álava del 18 de

\footnotetext{
${ }^{20}$ Ibídem, 11 de junio de $1885, \mathrm{~s} / \mathrm{n}$.

${ }^{21}$ Ibídem, 19 de junio de 1885 , s/n.

22 Ibidem, julio y agosto de $1885, \mathrm{~s} / \mathrm{n}$.

23 Ibidem, 19 de junio de 1884, s/n.

${ }^{24}$ Ibidem, 11 de junio de 1886, s/n.
} 
junio de $1886^{25}$ y también otra carta del Gobernador de la Provincia, diciendo que sus ocupaciones le impiden ir al concierto de esa noche del 19 de junio de 1886. El 20 de junio de 1886 se celebra otro concierto en la Academia ${ }^{26}$.

\section{Repertorio}

Desgraciadamente, no tenemos demasiadas noticias de los programas ejecutados y tampoco se conserva un archivo propio del Orfeón. Músicos como Odero o los Gálvez escribieron obras para coro de voces iguales que se conservan en el Archivo Provincial y que suponemos eran interpretados por el Orfeón, pero lo cierto es que no tenemos suficientes nombres de obras para hacer un estudio comparativo. En el archivo del Conservatorio se conserva la "Misa en Dom" de Escobar a voces iguales ${ }^{27}$ y en el archivo de la banda se conserva la misa "Adveniat Regnum Tuum" a tres voces iguales, del Pbro. Pedro de Bilbao ${ }^{28}$.

"El repertorio habitual del Orfeón era el de piezas de carácter religioso y de zarzuelas, con una particella importante para el coro ("Bohemios", de Amadeo Vives, "La canción del Olvido", de José Serrano o "El barberillo de Lavapiés", de Francisco Asenjo Barbieri)"29.

Según el acta de la Junta de 21 de junio de 1885 se reúnen para estudiar las audiciones y la composición de los programas: Odero propone dos coros a voces solas de Blaré, otros dos de Valera Silvari, "Dos cazadores" de Llurva y "El amanecer" de Eslava. Del repertorio de la Academia, "La Viña” de Odero (Partitura n. '1), "Rondó Oriental" de Henz, "Ronda y Marcha" de Cherubini y el "Eia mater" de Rossini se aceptan por unanimidad. ${ }^{30}$ En el concierto del 17 de septiembre se interpretan obras de Meyerbeer, el "Ave M" de Odero y "La Berceuse", de Chopin, y al final del concierto el "Inflamatus" n. o8 del "Stabat Mater" de Rossini. "La Viña" de Odero es interpretada por el coro del Orfeón y las alumnas del Instituto. ${ }^{31}$ En el programa de concierto de la Academia Santa Cecilia, dirigida por Odero el jueves 6 de mayo de 1886 interpretan "Poeta y aldeano" de Suppé, la "Misa", un motete y una plegaria de Odero $^{32}$.

\footnotetext{
25 Ibidem, 18 de junio de 1886, s/n.

${ }^{26}$ BPC, Hemeroteca, Diario de Cádiz, 20 de junio de 1886, s/f.

27 AHPC, Archivo del Conservatorio, caja 4541, núm.1.

${ }^{28}$ ARCHIVO MUNICIPAL DE CÁDIZ (en adelante AMC), Archivo de la Banda Municipal, caja C4777.

${ }^{29}$ PIÑEIRO BLANCA, Joaquín: Actividades musicales en el Cádiz de la década de los veinte", Cádiz, Universidad de Cádiz, 1992, p. 41.

${ }^{30}$ AHPC, Orfeón Gaditano, caja 35638, 21 de junio de 1885, s/n.

${ }^{31}$ Ibidem, 17 de septiembre de 1885, s/n.

32 Ibídem, 6 de marzo de 1886, s/n.
} 


\section{Partitura n. ${ }^{0} 1$}

\section{"La Viña" composición de Alejandro Odero dedicada al Orfeón}

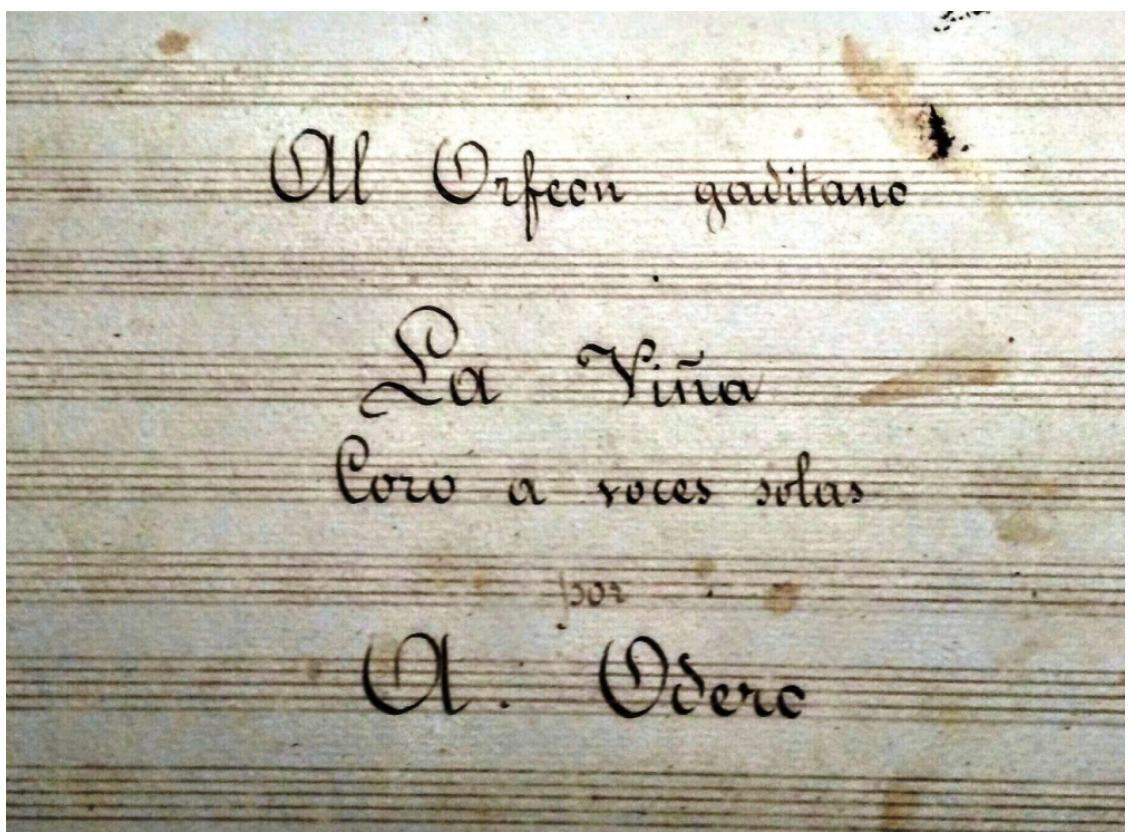

Fuente: Archivo Histórico Provincial. Archivo de Música del Conservatorio de Cádiz. Núm. 4583.

El 20 de junio de 1886 tiene lugar otro concierto en la Academia:

"Al concierto celebrado anoche, a beneficio del Orfeón Gaditano, asistió escogida concurrencia. Muy aplaudidos fueron todos los números del selecto programa, repitiéndose a instancias del publico, el aria del barítono del tercer acto de "Un ballo in maschera", cantada por D. Eduardo Romero, el coro "Raonda", "Marcha de Cherubini", por los alumnos de la Academia y el Orfeón, y la introducción, barcarola y plegaria de "El anillo de hierro", cantadas por los mismos" 33 .

El 17 de marzo de 1900 se publica el anuncio del programa de la Velada del día de San José, que se celebra a las ocho y media, al ser este el patrón del círculo Católico de Obreros. Entre otras obras, se programa el "Himno al Patriarca", de Gálvez, interpretado por el Orfeón del Centro, dirigido por el propio Gálvez, el “Coro de Repatriados” de Gigantes y Cabezudos y la "Ronda, marcha de Cherubini", también por el Orfeón. En la inauguración del curso de 1913, el día de santa Cecilia, se realiza un concierto dirigido por Gálvez, que se abre con el "Himno a Santa Cecilia" de Sancho Marraco, a voces solas, por el Orfeón. Se termina el concierto con "Malagueña" de Gálvez, con el Orfeón y Ana Márquez de solista ${ }^{34}$.

\footnotetext{
${ }^{33}$ BPC, Hemeroteca, Diario de Cádiæ, 20 de junio de 1886, s/f.
}

34 AHPC, Papeles del Conservatorio, c25633, 1913, s/n. 
El 22 de noviembre de 1919, el Orfeón del Regimiento de Cádiz núm. 67, interpreta "Himno a Santa Cecilia" de Gálvez, para coro y orquesta, y luego "Fantasía para piano, orquesta y coro en Dom” Óp. 80 de Beethoven. De final, “A la puerta del convento” de Grieg $^{35}$.

En la época en que ostenta la dirección, Escobar cambia el repertorio. En una reseña se habla de la preparación del "Himno a Valencia", "La muerte de la novia", "La doncella encantada", " Mi barquilla" y "Al salir de las deshojas"36.

\section{Evolución histórica del Orfeón}

Para tener una idea rápida de los acontecimientos más importantes del mismo podemos relacionar los mismos con la nómina de directores del Orfeón:

Tabla n. ${ }^{\circ} 2$

\section{Relación de directores, nombres y acontecimientos}

\begin{tabular}{|l|l|l|l|}
\hline 1883 & Dirección & Orfeón Gaditano & Rafael Marchante \\
\hline 1885 & Dirección & Orfeón Gaditano & Alejandro Odero \\
\hline 1886 & Dirección & Orfeón Gaditano & Enrique Guardón \\
\hline 1892 & Dirección & Orfeón Popular & Julio Junco \\
\hline 1893 & Dirección & Orfeón Hospicio & Camilo Gálvez \\
\hline 1894 & Dirección & Orfeón Hospicio & Damián López \\
\hline 1900 & Dirección & $\begin{array}{l}\text { Orfeón Círculo Católico } \\
\text { Obrero }\end{array}$ & Camilo Gálvez \\
\hline 1904 & Dirección & Orfeón Gaditano & Antonio Girau \\
\hline 1912 & Recuperación Orfeón & Orfeón Círculo Católico & José Gálvez \\
\hline 1915 & Separación Conservatorio & Obrero & \\
\hline 1916 & Dirección & Orfeón Gaditano & Rafael Lozano \\
\hline 1917 & & Orfeón Regimiento & \\
\hline 1920 & Dirección & Orfantería & Romero Gaditano \\
\hline 1929 & Dirección & Orfeón Gaditano & Eduardo Escobar \\
\hline 1930 & Dirección & Orfeón Gaditano & José Loubet \\
\hline 1932 & Dirección & Orfeón Gaditano & Miguel Berenguer \\
\hline 1933 & Dirección & Orfeón Gaditano & Joaquín Quintero \\
\hline 1936 & Proyecto Banda Municipal & & \\
\hline
\end{tabular}

Fuente: Elaboración propia a partir de las fuentes consultadas.

35 Ibidem, 22 de noviembre de 1919, s/n.

36 AMC, c434, carpeta de 1930. 


\subsection{Fundación y primera etapa}

\subsubsection{Dirección Rafael Marchante}

Es en el año 1883 cuando comenzamos a tener documentación del Orfeón. La fundación del mismo coincide con el periodo de mayor esplendor de creación de corales vascas, aunque no se establece una relación con ellas:

"Es durante este período cuando, según Nagore e Ibarretxe, se sitúa el auge del movimiento coral vasco de mayor importancia con un contenido eminentemente vasquista, con las fundaciones de los principales orfeones vascos..."37.

Casi con toda seguridad, la presidencia de Odero $^{38}$ de la Academia y del Orfeón es la causa segura de la fundación del mismo, especialmente, su formación francesa de juventud debió de empeñarlo en la creación de este tipo de asociación vocal. En un papel suelto del Archivo Provincial se recoge la fecha del 10 de mayo de 1883 como la de la fundación del Orfeón y se expresan los objetivos del mismo:

"Desde dicha fecha, y con constante perseverancia, han acudido el obrero y el artista a recibir educación musical consiguiéndose por este medio despertar la afición al estudio, y tal vez y sin que se den cuenta de ello, a abandonar otros lugares donde, a falta de distracciones instructivas, empleaba el corto jornal que disfrutaba..." 39.

También se conserva la propaganda buscando cantantes para el Orfeón (Fotografía n. ${ }^{\circ}$ 3). En estos papeles se marcan claramente los objetivos de la asociación, enfocados a la unión obrera en torno a la interpretación coral y la pedagogía básica de la música $^{40}$. A nivel administrativo, se realiza rápidamente la aprobación de la Sociedad del Orfeón Gaditano ${ }^{41}$.

En estos primeros años la vida interna del Orfeón va a verse envuelta en vaivenes constantes, por ejemplo, el 21 de octubre de 1883, recién inaugurado el mismo, se quiere sustituir al director Marchante ${ }^{42}$.

${ }^{37}$ CARBONELL I GUBERNA: Aportaciones...op. cit. p. 2, p. 497.

${ }^{38}$ SOBRINO, R. y ESPINOSA GUERRA, J.J.: "Odero", en Diccionario de la Música Española e Hispanoamericana. Madrid. Sociedad General de Autores y Editores, vol. 8, 2001, pp. 23-24.

39 AHPC, Orfeón Gaditano, c35638, 10 de mayo de 1883, s/n.

${ }^{40}$ Ibidem, Papel suelto, 10 de mayo de 1883, s/f.

${ }^{41}$ Ibidem.

${ }^{42}$ Ibidem, Correspondencia, 21 de octubre de 1883, s/f. 


\section{Fotografía n. ${ }^{\circ} 3$}

\section{Publicidad del Orfeón Gaditano en 1883}

\section{ORFEON GADITANO.}

\section{Enseñanza popular de la Música}

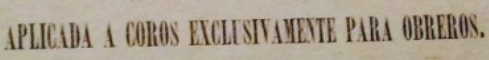

Los que deseen ingresar en esta Sociedad, pueden presentarse de ocho à nueve de la noche de los dias laborables, en la calle de la Compañía, núm. 13, establecimiento de calzados, donde se inscribiràn y adquiriràn màs detalles.

Fuente: AHPC, Orfeón Gaditano, caja 35638, 1883, s/n.

También se conservan las solicitudes de inscripción individual de cada orfeonista, (Fotografía n..$^{\circ}$ ) que son relativamente muy numerosas. La relación de los mismos nos permite deducir información de los coristas ${ }^{43}$ pues en ellos se hace hincapié en la situación familiar y en el oficio, también podemos observar que la composición es absolutamente masculina, así que, cuando el orfeón necesita de voces blancas, pide la colaboración de coros infantiles o se une a los coros de la Academia Santa Cecilia, que tienen una composición femenina más alta.

No conservamos documentación de concierto o actuación alguna del año de la fundación, hasta el 15 de Febrero de 1884 en que se realiza la primera actuación de la que tenemos constancia. De esta, se conserva el contrato entre el ayuntamiento y el orfeón para actuar los días de carnaval en el que el Orfeón se compromete a presentar una sección del coro compuesta de treinta orfeonistas a las órdenes del subdirector Julio Junco, la cual recorrería los sitios públicos más adecuados durante los tres días del carnaval, y a presentar un programa de las obras que vayan a ejecutarse. A cambio percibirán novecientas pesetas ${ }^{44}$, las piezas son acompañadas de un armonio portátil, el grupo está formado por 30 voces aproximadamente y cobran 300 pesetas por actuación y día, etc.

\footnotetext{
43 Ibidem, Carpeta con las solicitudes de ingreso de 1883, s/f.
}

${ }^{44}$ Ibidem, 15 de febrero de 1884, s/f. 


\section{Fotografía n. ${ }^{\circ} 4$}

\section{Solicitud de ingreso al Orfeón. 1883}

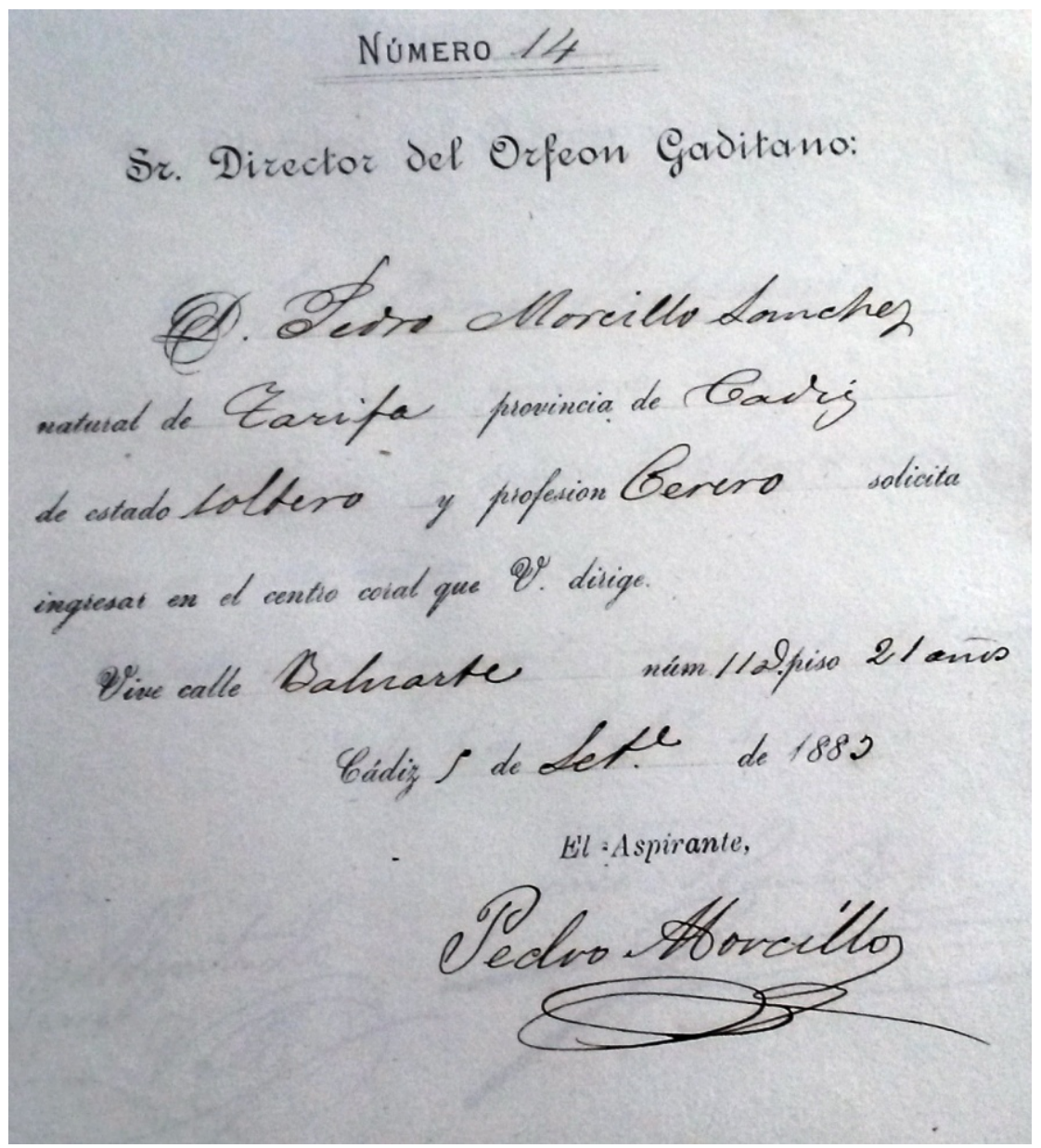

Fuente: AHPC, Orfeón Gaditano, caja 35638, 1883, s/n.

Igualmente, se conserva la lista de los orfeonistas que acuden a hacer dichos conciertos (Fotografía n. 5) y el "itinerario" de uno de los días: pasan por la Casa del Alcalde, el Gobierno Civil, el Gobierno Militar, la casa Aramburu, etc. Se conserva además la lista de gastos para el orfeón y por lo que vemos, estos debían ir disfrazados de frailes. El sueldo de los 33 orfeonistas es de 55 reales cada uno, el sueldo del director, 360 y el de los conductores del armonio de los tres días, 120.

Se conserva del día 7 de marzo un documento en el que Rafael Marchante, director, expresa la felicitación del Ayuntamiento y las muestras de satisfacción por parte de la prensa y del público por las actuaciones de Carnaval. Junto a estos, ejemplares impresos de los certificados de estudios, para rellenar a mano ${ }^{45}$.

45 Ibidem, Carpeta con plantillas de certificados, 1884, s/f. 


\section{Fotografía n. ${ }^{\circ} 5$}

Listado por cuerdas de los orfeonistas para el Carnaval de 1884

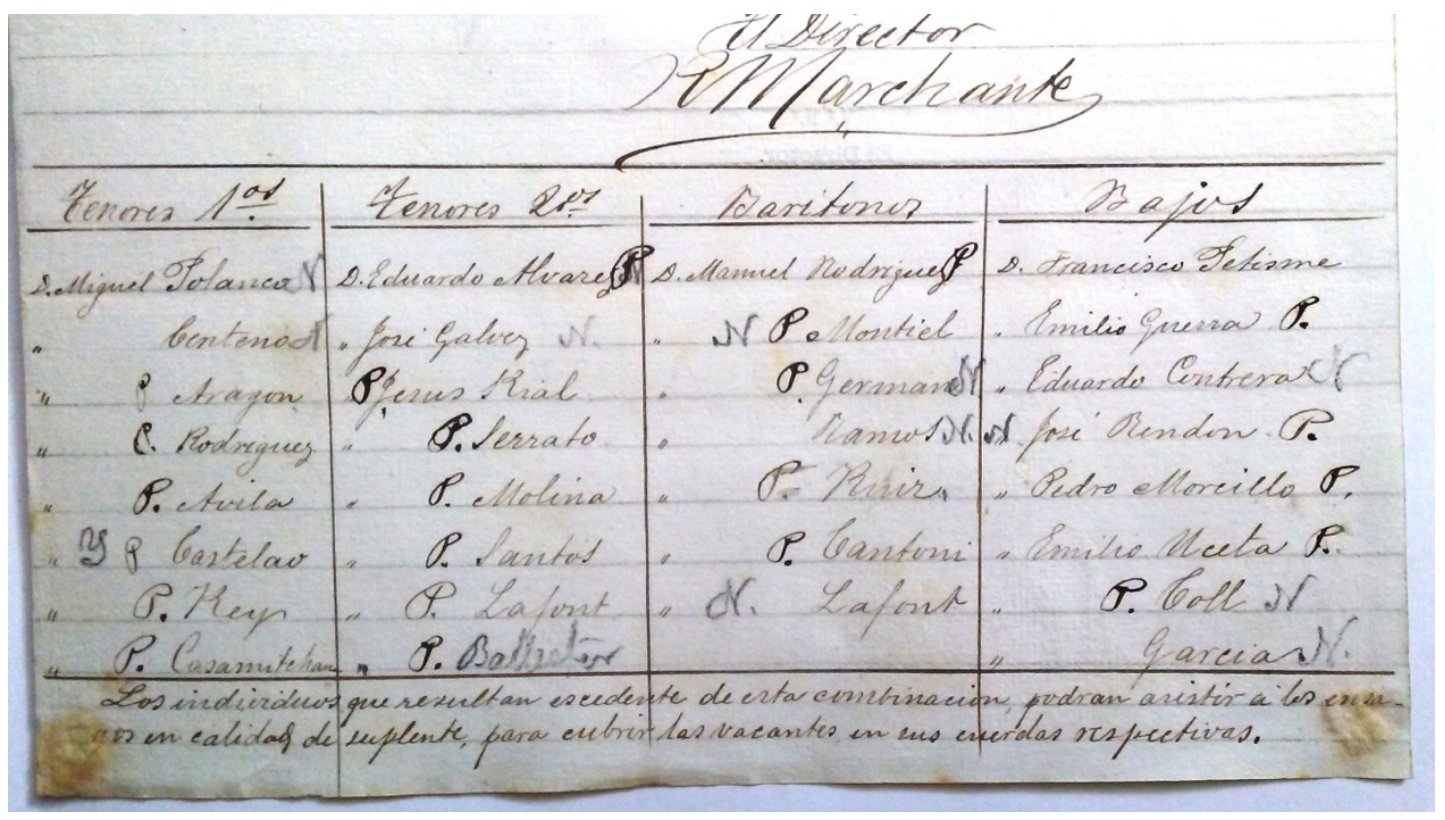

Fuente: AHPC, Orfeón Gaditano, caja 35638, 1884, s/n.

\subsubsection{Fiebre colérica. Dirección de Odero}

1885 es el año de la fiebre colérica en Cádiz. En los periódicos se suceden las noticias de fallecidos, entre los que se encuentran orfeonistas, y la organización de cocinas económicas para los afectados ${ }^{46}$. Aunque alterado, como vemos, por la situación general de la ciudad, el Orfeón sigue su vida habitual: el 31 de mayo, por acuerdo de la junta, son elegidos el presidente Alejandro Odero, y el secretario, Antonio Valls y Álvarez ${ }^{47}$, y el 13 de enero son invitados al inicio de curso, de nuevo, en el Ayuntamiento ${ }^{48}$. El 19 de abril se exponen de nuevo las quejas de algunos orfeonistas que no están contentos con el director, que sigue siendo Marchante ${ }^{49}$, más adelante, se noticia en prensa que el Orfeón ofrecerá enseñanza a las clases populares en la siguiente reseña:

"El orfeón gaditano ha decidido acometer una profunda remodelación. Tiene el pensamiento de establecer la enseñanza musical y proporcionar a la clase obrera medios de ilustración y su recreo por medio de conciertos populares..." 50 .

\footnotetext{
46 BPC, Hemeroteca, Diario de Cádiz, 16 de septiembre de 1885, s/n.

47 AHPC, Orfeón Gaditano, 31 de mayo de 1885, c35638, s/f.

48 Ibidem, 13 de enero de 1885, s/f.

${ }^{49}$ Ibidem, 19 de abril de 1885, s/f.

50 Diario de Cádiz, Efemérides, 20 de mayo de 2010, s/f.
} 
El 6 de julio se reúne una comisión para celebrar en Agosto un Certamen de Orfeones, pero lo dejan para el año siguiente ${ }^{51}$.

El 5 agosto se produce la dimisión de Odero sin expresar las causas ${ }^{52}$ y en otra carta del 12 de agosto, Julio J. Junco se queja de que cuando ha ido a dirigir los ensayos, no le permiten el paso a la Academia ${ }^{53}$. También se conserva un programa de la Academia Santa Cecilia del día 17 de septiembre: es un concierto a beneficio de la Junta de Defensa contra la epidemia colérica (Fotografía n. ${ }^{\circ}$ ) en el que la dirección está a cargo de Odero y el precio de la entrada es de 4 pesetas $^{54}$.

\section{Fotografía n. ${ }^{\circ} 6$}

\section{Programa del concierto a beneficio de los afectados de la epidemia}

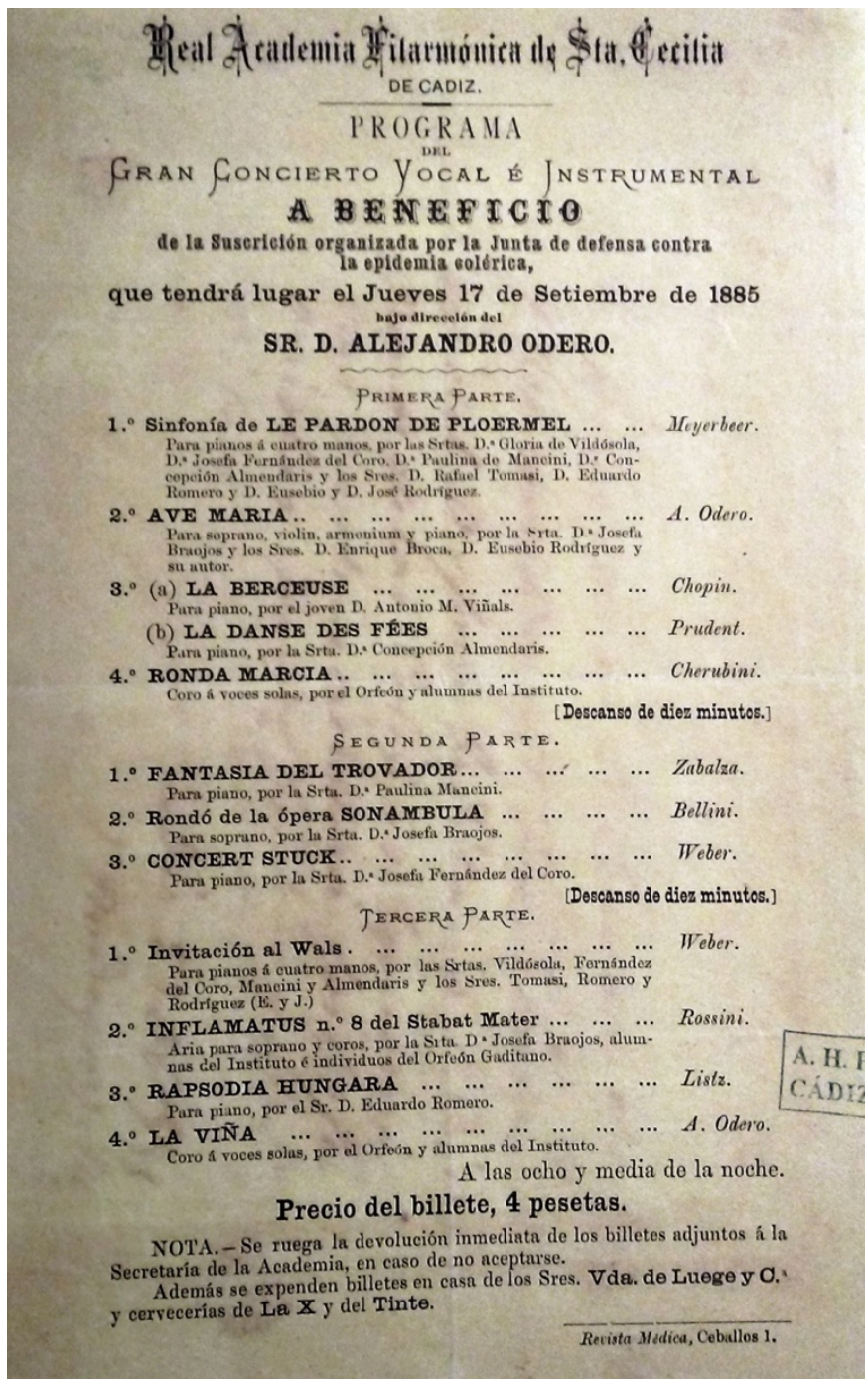

Fuente: AHPC, Orfeón Gaditano, caja 35638

\footnotetext{
51 AHPC, Orfeón Gaditano, c35638, 6 de Julio de 1885, s/n.

52 Ibídem, 5 de agosto de 1885 , s/f.

${ }^{53}$ Ibidem, 12 de agosto de 1885, s/f.

${ }^{54}$ Ibidem, 17 de septiembre de 1885, s/f.
} 
El 30 de octubre se produce una reunión de la comisión de reforma del Reglamento, lo que nos parece significativo con tan poco tiempo de vigencia ${ }^{55}$. El mes de noviembre la Junta de Defensa de la Epidemia, siguiendo con la función social y obrera del mismo, envía 150 bonos de las Cocinas Económicas al Orfeón (Fotografía n. ${ }^{\circ}$ 7) para repartir entre las personas que lo necesiten, de los cuales se conservan numerosos recibos de recepción ${ }^{56}$.

\section{Fotografía n. ${ }^{\circ} 7$}

\section{Recibo de bono de las cocinas económicas}

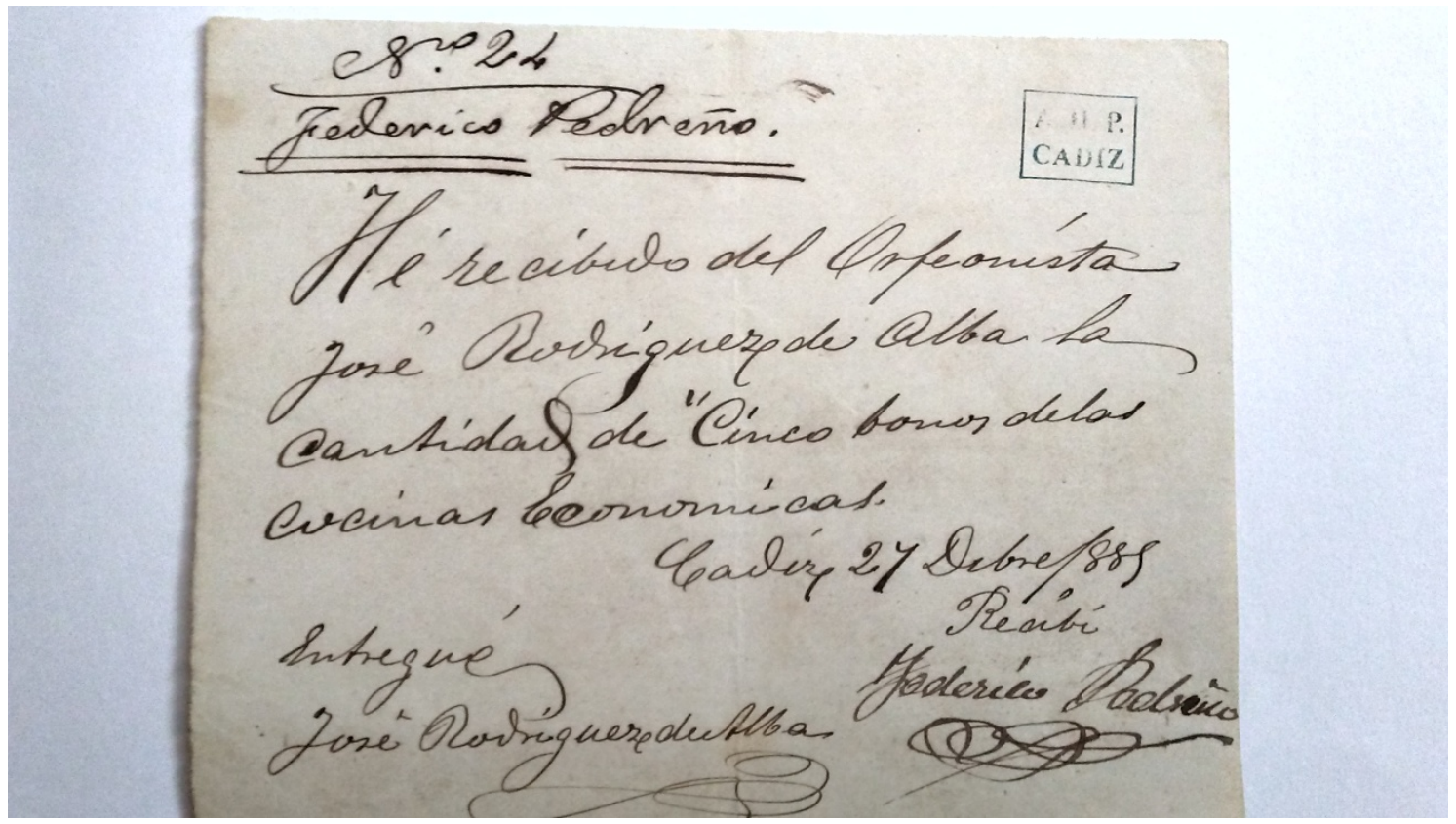

Fuente: AHPC, Orfeón Gaditano, caja 35638

\subsubsection{Dirección de Enrique Guardón}

El Orfeón, una vez pasada la epidemia, sigue con su vida habitual asistiendo a citas sociales y culturales, por ejemplo, se conserva la invitación para el jueves 14 de enero de 1886 de la Academia Gaditana de Ciencias y Artes, invitando al Orfeón a una velada literaria a la que se envía a los señores Broca, Picardo y Tomasi ${ }^{57}$. Tras la dimisión de Alejandro Odero, el 10 de febrero, se producen las votaciones para escoger una nueva dirección, que recae en “...Guardón para la sección de coros y Llompart para la capilla..." ${ }^{58}$. El 15 de marzo aparece otra

\footnotetext{
55 Ibidem, 30 de octubre de 1885 , s/f.

${ }^{56}$ Ibidem, noviembre de 1885, carpeta con recibos de las cocinas económicas.

${ }^{57}$ Ibídem, 14 de enero de 1886, s/f.

${ }^{58}$ BPC, Hemeroteca, Diario de Cádiz, 10 de febrero de 1886, s/f.
} 
invitación para una velada literaria en el local de la Academia, ${ }^{59}$ y el 6 de mayo se celebra otro concierto en la Academia Santa Cecilia, dirigido por Odero ${ }^{60}$. Después es invitado el Orfeón el 11 del mismo mes en el local de la Sociedad de Higiene, a la recepción del presidente. ${ }^{61}$

Se producen tensiones entre miembros de la junta: Eduardo Bellineni no acepta el cargo de Contador, aunque ha sido nombrado para ello, por carecer de la práctica y los conocimientos necesarios $^{62}$. Se conserva una carta de Marchante en la que expresa que el Orfeón nunca ha tenido archivo propio, lo que puede explicar que no se hayan conservado partituras del mismo ${ }^{63}$, aunque la citada junta reorganizadora lo escoge como vocal, pero este se excusa diciendo que no puede cumplir con las obligaciones del cargo ${ }^{64}$. Junco sigue quejándose por no haber sido citado a la reunión de la junta cuando aún no había dimitido de su cargo y expresa que esto demuestra el desgobierno de la junta y que ha sido "el que más se ha sacrificado y trabajado por el orfeón... "65.

Se celebra otro concierto el 14 de abril:

"Probablemente el sábado próximo se verificará en los salones de la Academia Filarmónica el concierto sacro que habíamos anunciado. Será reunión de sociedad. El viernes se celebrará el ensayo general. El programa es selecto. Habrá varios coros, algunos de más de setenta voces" 66 .

El 14 de mayo toma posesión la nueva junta directiva del Orfeón Gaditano, formada por Odero, Broca, Picardo, Canales, Ramonatcho y Vals ${ }^{67}$. Los ensayos se realizan en la Academia de Santa Cecilia y se comunica que está autorizado conceder los salones de la planta baja de la academia para el ensayo del Orfeón, mientras los gastos del alumbrado y otros que se originen corren a cargo de la sociedad, y que se tendrá cuenta el derecho de asistir con billete a los socios y socias de la misma, pero que los palcos se los reserva la academia para las autoridades y los dueños de la finca ${ }^{68}$.

\footnotetext{
59 AHPC, Orfeón Gaditano, c35638. 15 de marzo de 1886, s/f.

${ }^{60}$ Ibidem, 6 de mayo de 1886, s/f.

${ }^{61}$ Ibidem, 11 de mayo de 1886, s/f.

${ }^{62}$ BPC, Hemeroteca, Diario de Cádiz, 10 de marzo de 1886, s/n.

${ }^{63}$ Ibidem, 27 de marzo de 1886, s/n.

${ }^{64}$ Ibidem, 31 de marzo de 1886, s/n.

${ }^{65}$ Ibidem, 31 de marzo de 1886, s/n.

${ }^{66}$ Ibidem, 14 de abril de 1886, s/n.

${ }^{67}$ BPC, Hemeroteca, Diario de Cádiæ, 16 de mayo de 1886, s/n.

68 AHPC, Orfeón Gaditano, caja 35638, 15 de mayo de 1886, s/f.
} 


\subsubsection{Disolución Directiva. Crisis y traslados}

En estas mismas fechas se produce la dimisión de Alejandro Odero como presidente, lo que va a dar lugar a unas dimisiones en cascada, que supuestamente darían al traste con el Orfeón ${ }^{69}$. También dimite el Secretario, Antonio Valls y Álvarez, sin dar una razón en concreto, añadiendo haber estado desempeñando su labor desde 1883 al 5 de julio. El 6 de julio dimite el tercer vocal, Rafael Marchante, antiguo director del Orfeón, pero tampoco expresa una causa definida. El 8 de julio dimite también uno de los profesores, Enrique Juan Jalón, con palabras de agradecimiento hacia la agrupación. A pesar de esta supuesta desintegración del Orfeón, el 10 de julio de 1887 se recibe una carta invitando a una velada en conmemoración del segundo aniversario de José del Toro, que fue presidente, a la que son enviados de invitados Benito Picardo y Antonio Valls ${ }^{70}$.

\section{Fotografía n. ${ }^{\circ} 8$}

\section{Retrato de José $\mathbf{M}^{\mathrm{a}}$ Gálvez}

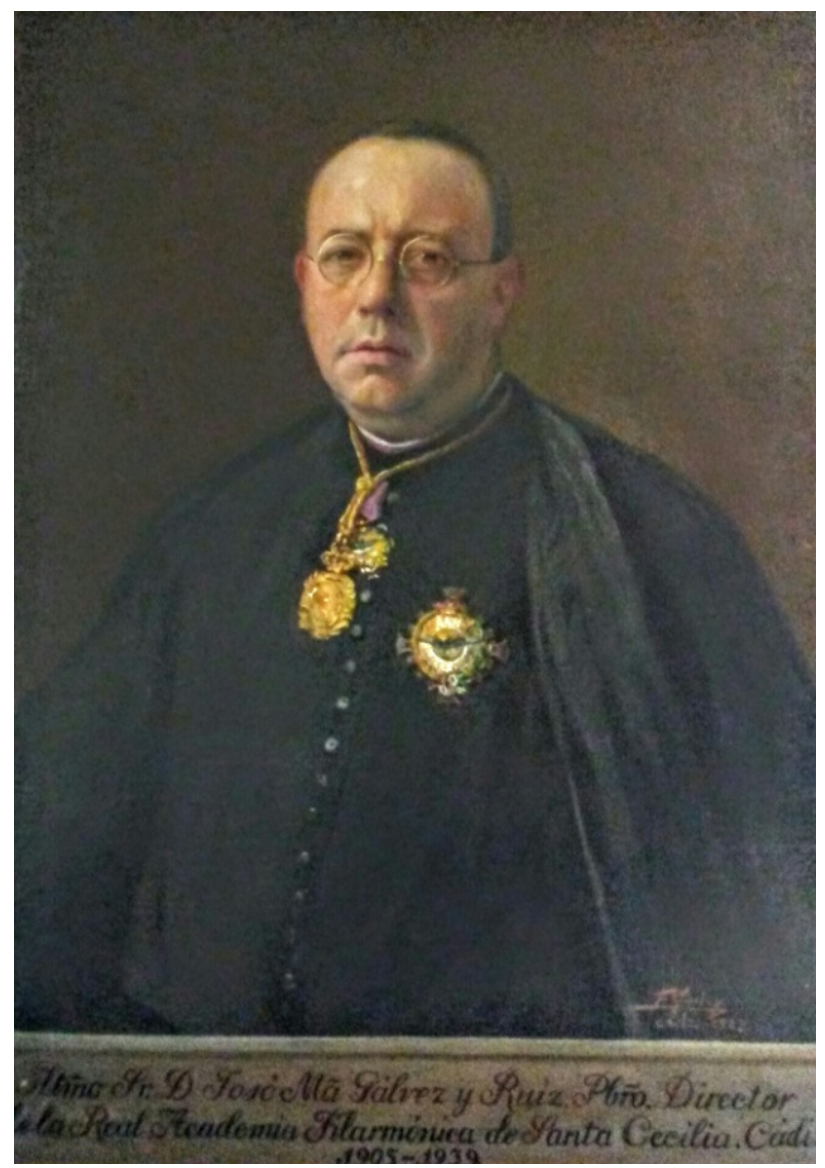

Fuente: Conservatorio de Cádiz. Realizada por el autor.

${ }^{69}$ Ibidem, 15 de julio de 1886, s/f.

${ }^{70}$ Ibidem, 10 de julio de 1887, s/f. 
En los años siguientes van a aparecer noticias del Orfeón, aunque a cuentagotas: el 4 de marzo de 1893 se publica el programa del Jueves Santo en el Hospicio, en el que aparece un orfeón propio y al año siguiente, de nuevo, aparece el Orfeón del Hospicio ${ }^{71}$ y en la descripción de la procesión de la Buena Muerte, aparece el Orfeón del Hospicio dirigido por Damián López (también director de la banda del Regimiento Infantería n. ${ }^{\circ}$ 54).

Seis años después tenemos constancia periodística del Orfeón en otro lugar y relacionado con otra sociedad: el 17 de marzo de 1900 se publica el anuncio del programa de la Velada del día de san José, en el Círculo Católico de Obreros. El Orfeón del Centro, dirigido por Gálvez (Fotografía n. ${ }^{\circ}$ ), interpreta las mismas composiciones que interpreta siempre el Orfeón ${ }^{72}$. Una explicación que podemos deducir a manera de hipótesis es que, una vez disuelto el Orfeón, los componentes quisieron seguir como conjunto, por lo que quizá fue acogido en principio por el Hospicio Provincial y después por el Círculo Católico Obrero.

\subsubsection{Regreso al Conservatorio. Dirección de José Gálvez}

El 22 de noviembre de 1910 tenemos noticia de un concierto de Santa Cecilia, en dicho centro de enseñanza, bajo la dirección de su director José Gálvez, por las alumnas de clase de canto y el Orfeón ${ }^{73}$, que vuelve a sus orígenes en la Academia. Sin embargo, no tendremos otras noticias suyas hasta el 18 de marzo de 1912 en el Centenario de las Cortes, en que se anuncia que el Orfeón de San Fernando es el encargado de ejecutar el Himno al día siguiente ${ }^{74}$.

"Interpretóse el magnífico himno en el centro de la plaza, la ejecución fue admirable, lo dirigió D Camilo Gálvez, y que, como es sabido, la música es de su hermano D José, y la letra de D Servando Camúñez."

El 20 de marzo en el Gran Teatro se repitió el Himno ${ }^{75}$.

Aprovechando el éxito obtenido, el 23 de marzo de 1912 se publica que sería interesante promover la afición a las corales ${ }^{76}$, y el 21 de abril de 1912 se anuncia que se está formando el Orfeón Gaditano ${ }^{77}$. Después aparece un artículo en Diario de Cádiz dedicado a

\footnotetext{
${ }^{71}$ BPC, Hemeroteca, Diario de Cádiæ, 23 de marzo de 1894, s/n.

${ }^{72}$ Ibidem, 17 de marzo de 1900, s/n.

${ }^{73}$ AHPC, Papeles del Conservatorio, c25633, 22 de noviembre de 1910, s/n.

${ }^{74}$ BPC, Hemeroteca, Diario de Cádiz, 18 de marzo de 1912, s/n.

${ }^{75}$ Ibidem, 20 de marzo de 1912, s/n.

${ }^{76}$ Ibidem, 23 de marzo de 1912, s/n.

${ }^{77}$ Ibidem, 1 de abril de 1912, s/n.
} 
la formación del Orfeón Gaditano ${ }^{78}$, más tarde se publica otro artículo dedicado al Orfeón, del que se dice que ya es una realidad ${ }^{79}$.

\subsection{Recuperación del Orfeón Gaditano. Dirección de Camilo Gálvez}

"El Orfeón Gaditano es creado en 1912, dentro de los actos de celebración del primer centenario de las Cortes de Cádiz, protegido por el Ayuntamiento con una subvención de veinte pesetas mensuales..." 80 .

El 26 de abril se produce la refundación del Orfeón en la Academia, presidida por el director Fernando García de Arboleya. Se ofrece la enseñanza gratis en la Academia para sus miembros y se recomienda la dirección de Camilo Gálvez, (Fotografía n. ${ }^{\circ}$ 9) que procede a hacer la clasificación de las voces con Enrique Posadas al piano y bajo la inspección de José Gálvez, que aconseja nivelar las voces y que se trate de tener algunas voces de tiple, con niños de 9 a 12 años. Posadas ocupa la Presidencia, y se acuerda que la cuota semanal sea de 25 céntimos y que la junta se encargue de redactar los estatutos ${ }^{81}$.

\section{Fotografía n. ${ }^{\circ} 9$}

\section{Camilo Gálvez}

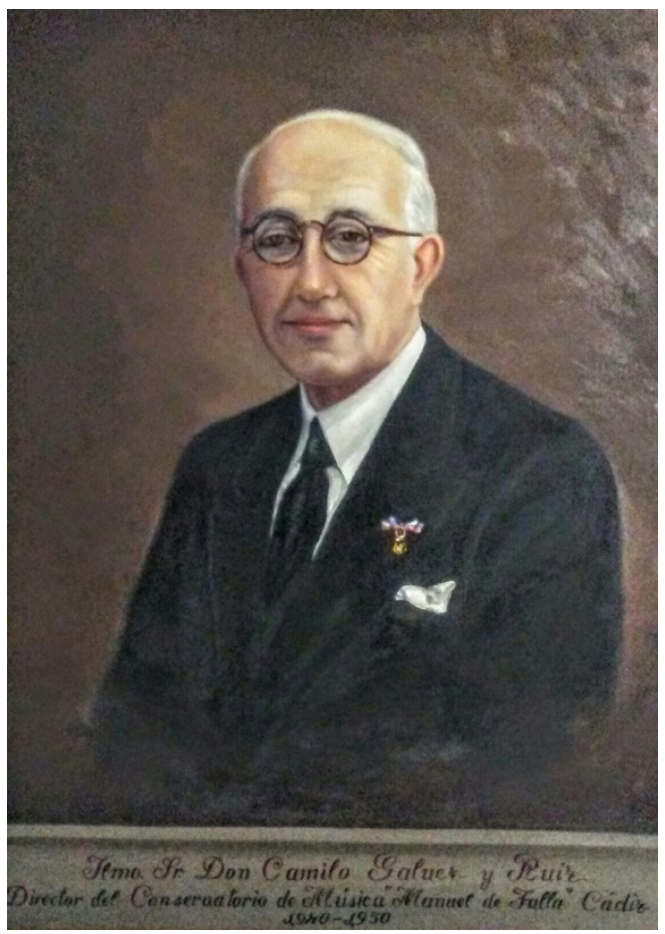

Fuente: Conservatorio de Cádiz. Realizada por el autor.

\footnotetext{
${ }^{78}$ Ibidem, 23 de abril de 1912 , s/n.

${ }^{79}$ Ibidem, 25 de abril de 1912, s/n.

${ }^{80}$ PIÑEIRO BLANCA. Actividades... op. cit. p. 7, p. 41.

${ }^{81}$ BPC, Hemeroteca, Diario de Cádiž, 26 de abril de 1912, s/n.
} 
El 19 de octubre el Padre Gálvez recibe la Encomienda de Alfonso XII, y se comenta que sería una buena ocasión para la presentación del Orfeón Gaditano, con dos obras del mismo $^{82}$. El 15 de marzo de 1913 se interpreta el oratorio en dos partes para voces y orquesta de Lorenzo Perosi "La Resurrección de Lázaro" 83 y el 16 de Marzo se publica una crítica extensísima del mismo ${ }^{84}$. En 1914 la nueva Junta dirigida por Fernández de Castro inaugura el nuevo local ${ }^{85}$.

“(1915) También en este año el Orfeón Gaditano se enemista con la Academia y se separa de él, como institución independiente, separándose de los hermanos Gálvez. Al contrario, parece que el conservatorio Odero desaparece temporalmente..." $" 86$.

El 12 de julio de 1915 se invita al Orfeón para que celebre dos conciertos en el Teatro del Parque Genovés, en agosto ${ }^{87}$, después, el 22 de junio de 1916, se programa un concierto en el kiosco del paseo de Canalejas ${ }^{88}$.

\subsubsection{El Orfeón del Regimiento}

El 21 de octubre de 1919 se organiza un Gran Concierto Sacro en las fiestas del 25 aniversario de la Beatificación de Fray Diego de Cádiz, en la misma Academia. Se interpreta de nuevo el Oratorio de Perossi, con los coros formados por el Orfeón del Regimiento de Cádiz núm. 67 y el conjunto coral e instrumental de la Academia ${ }^{89}$. El 22 de noviembre de 1919, reaparece reforzado con los profesores y alumnos, entre los que destaca Camilo Gálvez, interpretando las viejas piezas corales del orfeón anterior ${ }^{90}$.

"Esta asociación llega a la década de los veinte inmersa en una profunda crisis...", "...toda esta política de revitalización de la asociación se debía en gran medida a su director de aquellos años, el Señor Romero"91.

De nuevo, podemos intuir que el Orfeón pasó por un momento difícil y pasó a formar parte, por segunda vez, del Regimiento de Infantería.

\footnotetext{
${ }^{82}$ Ibidem, 19 de octubre de 1912, s/n.

${ }^{83}$ BPC, Hemeroteca, Diario de Cádiæ, 15 de marzo de 1913, s/n.

${ }^{84}$ Ibidem, 16 de marzo de 1913, s/n.

${ }^{85}$ Diario de Cádiz, Efemérides, 21 enero 2017.

${ }^{86}$ NAVARRO MOTA, Diego: La Historia del Conservatorio de Cádiz en sus documentos. Cádiz. Instituto de Estudios Gaditanos, 1976, p. 63.

${ }^{87}$ BPC, Hemeroteca, Diario de Cádiz, 21 de julio de 1915, s/n.

88 BPC, Archivo Corpus en Cádiz, 22 de junio de 1916, s/f.

89 AHPC, Papeles del Conservatorio, c25633. 21 de octubre de 1919, s/f.

${ }^{90}$ Ibidem, 22 de noviembre de 1919, s/f.

${ }^{91}$ PIÑEIRO BLANCA, Actividades... op. cit. p. 7, p. 41.
} 


\subsubsection{Nueva crisis y críticas al Orfeón}

En el Reparto de Premios de la Academia aparece el Orfeón, de nuevo unido a la Academia Santa Cecilia, el 22 de noviembre de $1921^{92}$ y al año siguiente se constata que sigue recibiendo una subvención del consistorio:

“...la de Don Maximiliano Caballero, presidente de la Sociedad Coral Orfeón Gaditano, solicitando el aumento de la subvención que tiene concedida dicha sociedad”93.

En otro cabildo del mismo año: “...el Sr. Alcalde manifiesta que abora hay que contestar urgentemente al Orfeón Gaditano... "94.

En 1923 aparece un artículo que habla del nombramiento de Miguel Delgado de Mendoza como presidente del Orfeón Gaditano y que critica que ya no depende de la Sociedad que lo creó, que desapareció el Centro de Cultura y que no debería cobrar una subvención del ayuntamiento ${ }^{95}$. En esta línea, la Asociación de Cultura Musical, el 23 de junio, recoge la queja de que el Orfeón se dedica más a representaciones que a música coral ${ }^{96}$. En 1924 los directivos del Orfeón son: Presidente, Romero Ruiz, Vicepresidente, Miguel Marchante, Secretario, José Rendón y Vicesecretario, Diego Álvarez. El 5 de septiembre del mismo año, a pesar de las críticas, el Orfeón vuelve a sus funciones corales:

"El conjunto coral, pilar constituyente de esta entidad, estaba compuesto por doce sopranos, dieciséis tenores, nueve barítonos y diez bajos. Una nómina irregular si tenemos en cuenta el importante desequilibrio entre el número de voces femeninas y masculinas (y entre aquellas, además, no encontramos contraltos). A pesar de estas carencias, las críticas recibidas por sus conciertos son buenas" ${ }^{\prime 97}$.

El 13 de febrero de $1926^{98}$ se anuncia la visita de la Estudiantina del Centro Filarmónico Lucena de Córdoba, compuesto por 85 obreros de distintos ramos con escasos conocimientos musicales, que son recibidos por el vicepresidente del Orfeón Gaditano, Meléndez. El 1 de marzo de 1927 aparece la noticia de uno de los actos preferidos de la Asociación que se repetirá a lo largo de los años: los bailes.

\footnotetext{
${ }^{92}$ AHPC, Papeles del Conservatorio, c25633, 22 de noviembre de 1921, s/f.

${ }^{93}$ AMC, Actas capitulares, n. ${ }^{\circ} 8$ del 20 de mayo de 1922, punto $9^{\circ}$.

${ }^{94}$ Ibídem, n. ${ }^{\circ} 18$ del 25 de junio de 1922 , punto $7^{\circ}$

${ }^{95}$ BPC, Archivo, Cultura Musical. 15 de mayo de 1923, caja PA-PP-20

${ }^{96}$ Ibidem, 25 de junio de 1923.

${ }^{97}$ PIÑEIRO BLANCA: Actividades... op. cit. p. 7, p. 42.

${ }^{98}$ BPC, Hemeroteca, Diario de Cádiæ. PA-PP. 13 de febrero de 1927, s/n.
} 
"Desde las diez de la noche no cesó de bailar un momento el elemento joven, resultando una velada sumamente brillante y animada. Las batallas de confetis y serpentinas se generalizaron desde el primer momento, transcurriendo horas agradabilísimas..." 99.

El 25 de mayo de 1927 llegan a Cádiz los Coros de Ruada. Para recibirlos se personan por el Orfeón Gaditano el presidente Francisco Corrales, el vicepresidente Joaquín Quintero, el tesorero Pedro de Vera y Monge, etc., mientras que la madrina del Orfeón, Mercedes Posada, regala una cinta para la bandera ${ }^{100}$.

Aparecen de nuevo los contratos para el percibo de la subvención de la Academia, el Conservatorio Odero y el Orfeón, que son firmados por el presidente Francisco Corrales Carrasco y por los que reciben 1000 pesetas. A cambio, se obligan a cumplir los fines para lo que fueron fundados "en el orden de cultura musical y declamación", a cooperar en los coros de las fiestas organizadas por la corporación y a presentar una memoria anual ${ }^{101}$.

\subsubsection{Revitalización del Orfeón. Dirección de Eduardo Escobar}

El 28 de mayo de 1928 se publica que el Orfeón organiza una Cruz de Mayo y comienza una nueva etapa. Entre los aspirantes a músicos de la Banda Municipal en 1928 aparece el expediente del subdirector del Orfeón, José Loubet Cirilo, músico que intentó ese mismo año organizar la banda municipal, pero el ayuntamiento no lo autorizó, sino que encargó la misma al músico Eduardo Escobar, que se convierte en el nuevo director del Orfeón. La parte del coro de tiples la dirige otra antigua conocida de la Academia Santa Cecilia, la profesora Carmen Rivas ${ }^{102}$ y además, el Orfeón sigue realizando su actividad preferida, los bailes, como el del 13 de febrero de 1929, ${ }^{103}$ o el del 4 de mayo de 1929:

\footnotetext{
"Dada la brillantez y éxito obtenido en la primera reunión de confianza, celebrada por esta simpática Sociedad, promete estar animadísima la que mañana domingo 5 de mayo tendrá lugar en los hermosos salones que posee en su domicilio en Sagasta 7. Amenizará la velada la excelente orquestina que dirige el veterano profesor Don Bartolomé Llompart"104.
}

\footnotetext{
99 Ibidem, 1 de marzo de $1927, \mathrm{~s} / \mathrm{n}$.

100 Ibídem, 5 de marzo de 1927, s/n.

101 AMC, Expediente de Instrucción Pública n. ${ }^{\circ} 22$, c5999, enero de 1928.

102 AMC, c434, 10 de junio de 1930.

103 BPC, Hemeroteca, Diario de Cádiæ, 13 de febrero de 1929, PA-PP, s/n.

104 Ibídem, 4 de mayo de 1929, s/n.
} 
Se conserva otro semejante del 7 de mayo de $1929^{105}$. A partir del 10 de febrero de 1930 se empieza a emitir publicidad solicitando nuevos orfeonistas ${ }^{106}$. Además, como sociedad, el Orfeón organiza todo tipo de conciertos, como el del 5 de marzo de 1930, en el que se constata la actuación de la Estudiantina de la Facultad de Medicina ${ }^{107}$.

El 16 de Agosto se prepara el kiosco de música para el concierto de presentación de la Banda Municipal junto al Orfeón. El domingo siguiente al 22 de agosto 1930 se produce el estreno en el Parque Genovés dirigido por el subdirector de la banda ${ }^{108}$, Rufino Olmos, que dimite de la banda el 25 de agosto, sin embargo, algún suceso que desconocemos ocurre, ya que Olmos se ha hecho cargo del Orfeón y a los pocos días, en el Cabildo del Ayuntamiento del 30 de agosto de 1930, se informa de la dimisión de Eduardo Escobar (Fotografía n. $\left.{ }^{\circ} 10\right)$, Maestro Concertador del Orfeón ${ }^{109}$.

\section{Fotografía n. ${ }^{\circ} 10$}

\section{El Orfeón Gaditano en Jerez}

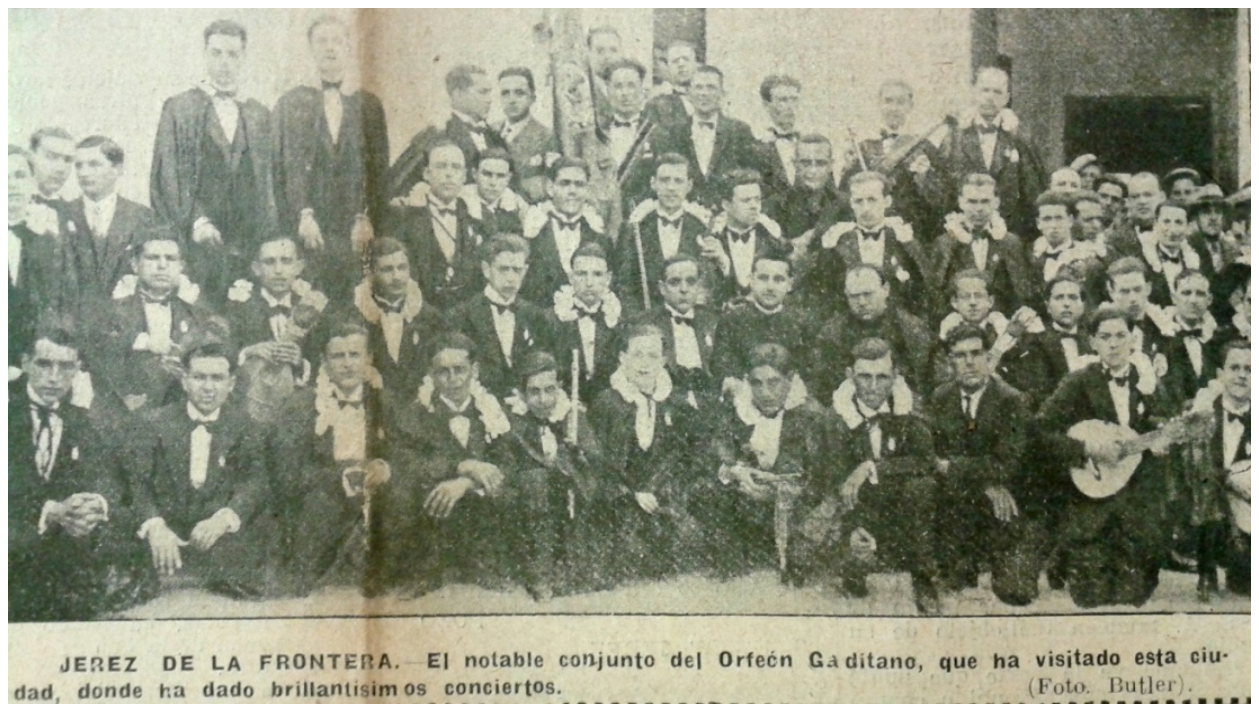

Fuente: BPC, Hemeroteca, Diario de Cádiz. 5 de marzo de 1931.S/n de hoja. Eduardo Escobar aparece en el centro, sentado a la derecha del sacerdote.

En 1930 la revista de la Asociación Cultura Musical publica un artículo sobre un concierto realizado en el Gran Teatro Falla, a cargo del Orfeón, que se repite el domingo de Piñata en la plaza de Mina. Habla de la composición del mismo con obreros, y de muchachos

\footnotetext{
105 Ibídem, 7 de mayo de 1929, s/n.

106 Ibídem, 10 de febrero de 1930, s/n.

107 Ibidem, 5 de marzo de 1930, s/n.

108 AMC, Negociado de Banda, c434, carpeta de 1930.

${ }^{109}$ AMC, Libro de Actas L10401, Acta del pleno del 30 de agosto de 1930, n. ${ }^{\circ} 10$ punto 17.
} 
que reciben clases de música. Se informa que el director es José Loubet y que el presidente es José Anduaga ${ }^{110}$. En 1931, en los actos republicanos de la plaza de toros (Fotografía n. ${ }^{\circ} 11$ ) se celebra un concierto, con la primera parte a cargo del Orfeón Gaditano y la segunda de la banda ${ }^{111}$. En 1932 hay un concierto en la Agrupación de la Prensa:

"Los orfeonistas ejecutaron un programa verdaderamente escogido y con singular acierto y afinación, pues se trata de un conjunto de entusiastas jóvenes perfectamente organizados, bajo la dirección de su profesor Miguel Berenguer ${ }^{112}$.

\section{Fotografía n. ${ }^{\circ} 11$}

\section{Actos 1er. Aniversario de la República en la plaza de toros de Cádiz}

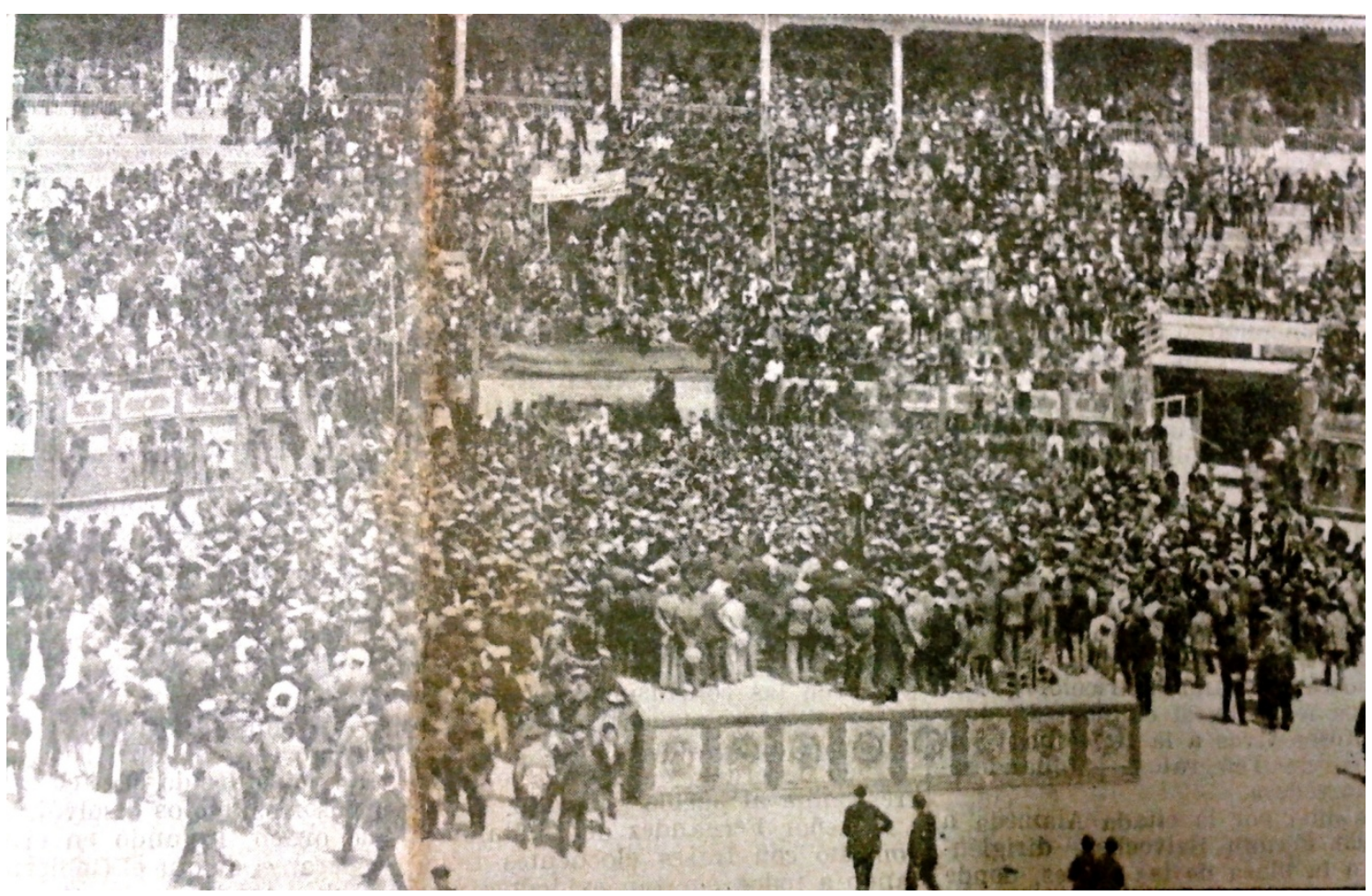

Fuente: BPC, Hemeroteca, Diario de Cádiz. 4 de mayo de 1931.

El mismo año el Orfeón organiza el Baile de Piñata ${ }^{113}$ y después, el 18 de octubre un recital poético ${ }^{114}$. De 1933 se conserva una carta nombrando a Manuel Álvarez como inspector del Orfeón, en la que se elogia la labor educativa de Escobar, que recibe una gratificación y retorna a la dirección del mismo ${ }^{115}$. El 27 de febrero de 1933 el jurado del

\footnotetext{
110 BPC, Hemeroteca, Música y Músicos, marzo de 1931, caja 25.

111 AMC, Negociado de Banda, caja C434, carpeta de 1931.

112 BPC, Hemeroteca, Diario de Cádiæ, 27 de enero de 1932, s/n.

${ }^{113}$ Ibidem, 14 de febrero de 1932, s/n.

114 Ibidem, 18 de octubre de 1932, s/n.

115 AMC, Negociado de Banda, c434, carpeta de 1930.
} 
concurso de las agrupaciones carnavalescas estaba formado, entre otros, por Escobar $y$ “...Joaquín Quintero director del Orfeón Gaditano"116. En 1935 se noticia otra actividad social del Orfeón curiosa: el concurso de mantones y de feos:

"El primer premio fue para la señorita Mariquita Marchante, que lucía un precioso mantón negro bordado en colores. El segundo premio fue para la señorita Rosita Martínez. Finalmente las muchachas premiadas otorgaron el premio al más feo de la velada al joven Manuel Ortiz"117.

\subsubsection{Decadencia}

El 27 de enero de 1936 se prepara la desaparición de la Banda Municipal, pero los músicos de la misma pretenden salvarla asociándola al Orfeón, así que otra opción que se baraja es contratar a la Banda del Hospicio Provincial para que, mediante subvención, se encargue de celebrar los conciertos. El 28 se vuelve a reunir la comisión con la intención de no seguir en la línea de lo hablado con la Diputación y estudiar la posibilidad del tema del Orfeón Gaditano ${ }^{118}$. El día 30 se solicita a Anduaga y Escobar un proyecto en este sentido ${ }^{119}$ y posteriormente, se acuerda facultar a Anduaga, presidente de la entidad, para contratar con el ayuntamiento los contratos de conciertos de la banda. Al final, el 3 de Febrero se autoriza ejecutar el contrato con el Orfeón ${ }^{120}$.

El día 12 el presidente del Orfeón informa al Ayuntamiento que han designado para el cargo de Director de la banda a Eduardo Escobar ${ }^{121}$, pero este termina por ser despedido y pone una demanda al ayuntamiento. En esta época convulsa José de Veiga pretende hacerse con el contrato del ayuntamiento y se pone al servicio del consistorio con una agrupación dependiente de UGT, pero el ayuntamiento no accede a ello y Escobar será readmitido. En marzo el Orfeón dirigido nuevamente por Escobar pretende reorganizar la banda, pero este contrato no llega a fructificar por cambios en el Ayuntamiento.

116 VILLANUEVA IRADI, Miguel. El Carnaval de Cádiz durante la $2^{\circ}$ República Española (1931-1936). Ensayo sobre un carnaval probibido. Chiclana de la Fra., Editorial Fundación Vipren, 2007, p. 45.

117 Diario de Cádiz, Efemérides, 29 de mayo de 2010.

https://www.diariodecadiz.es/efemerides/mantones-feos-Orfeon-Gaditano $0 \quad 373162717 . \mathrm{html}$

Página visitada el 2 de septiembre de 2019.

118 AMC, Negociado de Banda, c441, carpeta de 1936. 28 de enero, s/f.

119 Ibidem, 30 de enero de 1936, s/f.

${ }^{120}$ Ibidem, 2 de febrero de 1936, s/f.

${ }^{121}$ Ibídem, 12 de febrero de 1936, s/f. 
"Para el servicio de banda en el año actual figuran en presupuesto 60000 pesetas y se establecen negociaciones con el Orfeón Gaditano, para ello no llegándose a la firma del contrato por haber cesado la Comisión Gestora" 122 .

El 15 de junio el ayuntamiento designa al concejal Camerino para estudiar el tema de la banda, aunque en el siguiente escrito parece inclinado a hacer un contrato con la Agrupación Artística de Trabajadores de la Música. Después se realiza un Inventario de la Academia de la Banda con los enseres que se prestan en usufructo al Orfeón ${ }^{123}$.

\section{Conclusión. La herencia del Orfeón}

\section{Fotografía n. ${ }^{\circ} 12$}

\section{Enrique Matute}

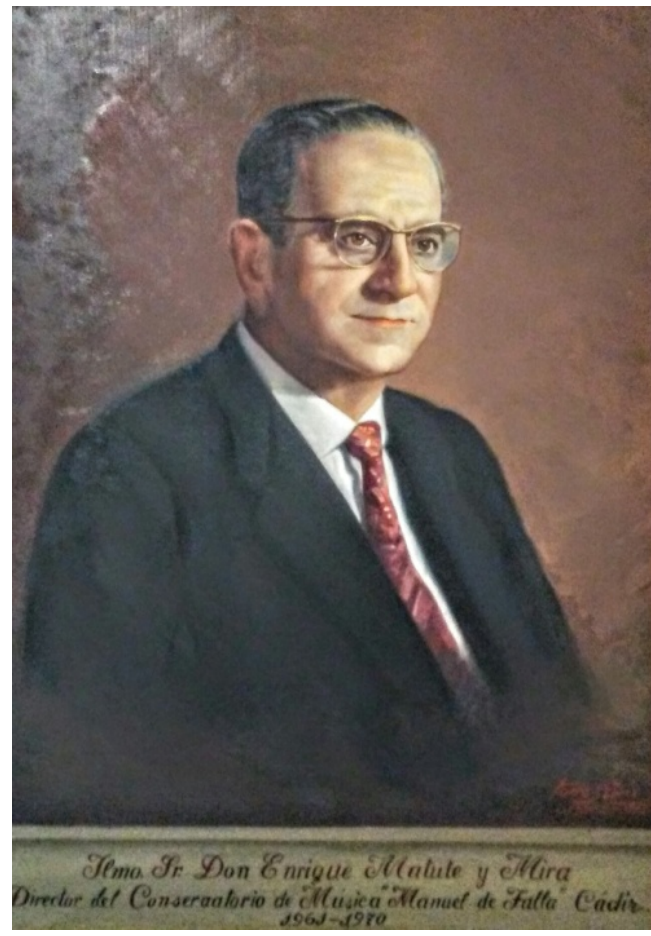

Fuente: Conservatorio de Cádiz. Realizada por el autor.

Los sucesos previos a la Guerra Civil y el propio conflicto debieron ser definitivos para la disolución del Orfeón, sin embargo, siguiendo con esa misma tradición coral, queda en Cádiz la Masa Coral Gaditana (Fotografía n. ${ }^{\circ}$ 13), que aparece como entidad autónoma en los papeles del Conservatorio, y que goza de logros importantes en los años 44-45 ${ }^{124}$, sin

122 Ibidem, marzo de 1936, s/f.

${ }^{123}$ Ibídem, 15 de junio de 1936. Expediente número 14.

${ }^{124}$ La historia del... op. cit. p. 21. 
embargo, ensaya en los locales del Conservatorio, siguiendo la tradición del Orfeón. Sus directores son Camilo Gálvez, Antonio Escobar y Enrique Matute (Fotografía n. $\left.{ }^{\circ} 12\right)^{125}$. Antiguos componentes de la Masa Coral son integrantes de corales actuales.

\section{Fotografía n. ${ }^{0} 13$}

\section{Masa Coral Gaditana. 1959}

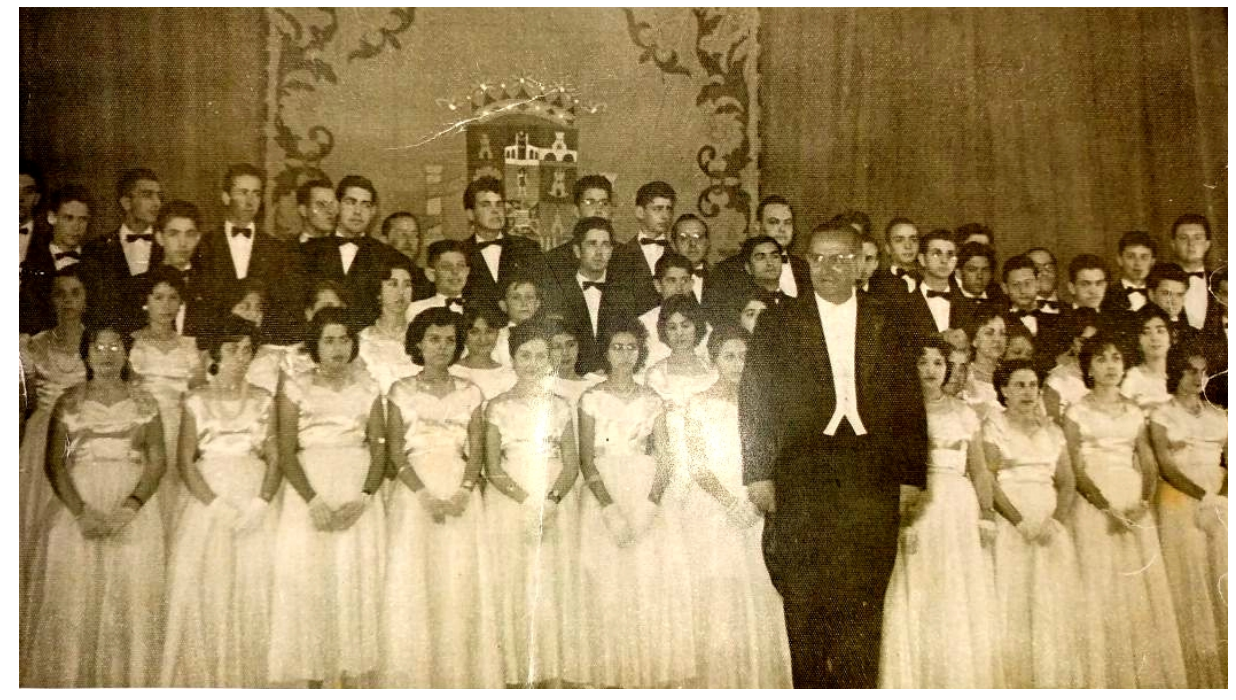

Fuente: Cesión de un particular.

En definitiva, se demuestra que el movimiento coral en Cádiz es independiente del resto de España, que estuvo encabezado por Darhan y Otero, ambos de formación francesa, que el Orfeón fue bastante popular en su época, ya que incluso sin tener objetivos musicales era capaz de tener un papel social relevante en la organización de eventos, y que marcó la línea a seguir del movimiento coralista en Cádiz, tradición que se ha perpetuado hasta nuestros días en las agrupaciones que existen en la capital gaditana.

125 PAJARES BARÓN, Máximo: Catálogo del Archivo de Música de la Catedral de Cádiz: Granada, Centro de Documentación Musical de Andalucía, 1993, p. 376. 